\title{
Evaluation of antioxidant potential of pigments extracted from Bacillus spp. and Halomonas spp. isolated from mangrove rhizosphere
}

\author{
Shivali Patkar, Yashodhara Shinde, Priyanka Chindarkar, Pampi Chakraborty * \\ St. Xavier's College (Autonomous), Mumbai, India
}

\begin{abstract}
The present study aimed to isolate different pigment-producing bacteria from the mangrove rhizosphere habitat and to extract their pigments for evaluating their antioxidant and sun-protective properties. Three pigment-producing bacterial cultures were isolated from soil samples and were identified by morphological analysis and 16S rDNA sequencing. The pigments were isolated by the solvent extraction method and named as MZ (Pink), Orange, and Yellow. They were characterized by Fourier Transform Infrared (FTIR) and UV-Vis spectroscopy. The sun protection factor (SPF) values of these pigments were then determined using the Mansur equation. The total polyphenol content was estimated by the Folin-Ciocâlteu method, and the antioxidant activity of the pigments was determined using DPPH (2,2-diphenyl-1-picrylhydrazyl), FRAP (ferric reducing antioxidant power), and ABTS (2,2-azinobis-3-ethyl-enzothiazoline-6-sulfonic acid) assays. The in vitro antioxidant potential of the pigments in the presence of oxidative stress $\left(\mathrm{H}_{2} \mathrm{O}_{2}\right)$ was confirmed in the mouse macrophage cell line RAW264.7 by using the MTT (3-(4,5-dimethylthiazol-2-yl)-2,5-diphenyl tetrazolium bromide) assay. The pigment-producing bacterial isolates were identified as Bacillus infantis (MZ), Halomonas spp. (Orange), and Bacillus spp. (Yellow). The pigments were found to be carotenoid in nature, and the SPF values were in the range of 3.99 to 5.22. All three pigments had high polyphenol content ( 22 to $48 \mu \mathrm{g}$ tannic acid equivalent) and showed significant antioxidant properties in both chemical and cell line-based studies. The results of this study indicate that these pigments have the potential to be used as an antioxidant agent and can be further developed as a pharmaceutical compound.
\end{abstract}

Key words: biopigment, antioxidant, SPF, rhizosphere soil

\section{Introduction}

Living organisms including microorganisms are known to synthesize natural pigments (Rao et al., 2017), which are primarily pharmacologically active compounds. These secondary metabolites confer protection to bacteria against extreme temperature, ultraviolet radiation, and desiccation (Wada et al., 2013). Pigment production is also triggered by microorganisms through quorum-sensing mechanisms to inhibit or kill other microorganisms present in their surroundings (Soliev et al., 2011).

Microorganisms are a preferred source of pigments because of ease of extraction, production manipulation, and availability throughout the year. Microbial pigments are also nontoxic and biodegradable as compared to their synthetic counterparts (Rao et al., 2017). Because of their therapeutic nature, as shown by their remarkable antioxidant, cytotoxic, antimicrobial, and anticancer properties, bacterial pigments have a wide range of applications in pharmaceutical industries (Soliev et al., 2011). Carotenoid pigments play a vital role in protecting bacterial and plant chlorophyll from photo-destructive reactions and are therefore known as photo-protective agents (Sandmann, 2014; Kushwaha et al., 2020). Carotenoids act as antioxidants (Sarker and Oba, 2018a, 2018b, 2020a, 2020b) and are used as vitamin supplements, as their intake prevents photo-aging and sunburns (Numan et al., 2018). Certain quinone-derived pigments demonstrate antimicrobial, insecticidal, and anticancer activities (Saha et al., 2008; Numan et al., 2018).

* Corresponding author: St. Xavier’s College (Autonomous), Mumbai, India; e-mail: pampi.chakraborty@xaviers.edu 
In the human body, oxidative stress is generated due to the accumulation of free radicals, which is the underlying reason for the development of chronic neurological and cardiovascular diseases and cancers (Phaniendra et al., 2015). Antioxidants possess the ability to destroy free radicals by donating electrons, thereby resulting in their neutralization (Sarker and Oba, 2019a, 2020c, 2020d; Sarker et al., 2020a, 2020b). On the other hand, synthetic antioxidants are not preferable for long-term consumption because of their reported side effects (Phaniendra et al., 2015). Therefore, recent studies on antioxidants have focused on screening different natural compounds and evaluating their pharmaceutical activities (Agustina et al., 2021; Foong et al., 2021; Sakihama and Yamasaki, 2021).

In the present study, various microbial pigments were extracted from indigenous microorganisms isolated from a mangrove rhizosphere habitat. These pigments were characterized by UV-Vis spectroscopy and Fourier Transform Infrared (FTIR) analysis. The pigment production was optimized, and the antioxidant potential of the pigments was determined by chemical assays and an in vitro assay using a murine macrophage cell line.

\section{Materials and methods}

\section{Isolation and identification of the bacterial strains}

Mangrove soil and water samples (Mumbai; $19.352559^{\circ}, 72.847327^{\circ}$ ) were used to isolate the pigment-producing bacteria. The samples were cultured on nutrient agar (M001, HiMedia Laboratories, Mumbai) and incubated for $48 \mathrm{~h}$ at $37^{\circ} \mathrm{C}$. The obtained pigmented colonies were maintained on sterile nutrient agar slants and in glycerol stocks. These cultures were identified according to their morphological characteristics (Suresh et al., 2004; Vaz-Moreira et al., 2012; Tang et al., 2017) and $16 \mathrm{~S}$ rDNA sequencing.

\section{DNA extraction of the isolated bacterial cultures}

DNA extraction of all the cultures was performed by the phenol-chloroform method (Köchl et al., 2004). To extract DNA, $1 \mathrm{ml}$ of cell suspension from the overnight grown bacterial cultures was centrifuged at $5000 \mathrm{rpm}$ for 10 min to obtain cell pellet, to which $500 \mu \mathrm{l}$ of $10 \mu \mathrm{M}$ Tris-EDTA buffer ( $\mathrm{pH} 8.0$ ) and $20 \mu$ l Proteinase $\mathrm{K}$ $(20 \mathrm{mg} / \mathrm{ml})$ were added. The mixture was vortexed, and an equal volume of buffered phenol ( $\mathrm{pH} 8.0$ ) was added; this mixture was vortexed and centrifuged at $14000 \mathrm{rpm}$ for $10 \mathrm{~min}$. The aqueous phases were collected, followed by the addition of $500 \mu \mathrm{l}$ of chloroform, vortexing, and centrifugation at $14000 \mathrm{rpm}$ for $10 \mathrm{~min}$. The aqueous phases were collected once more, and $50 \mu \mathrm{l}$ of $3 \mathrm{M}$ sodium acetate solution and $800 \mu \mathrm{l}$ of $100 \%$ ethanol were added. This solution was refrigerated at $-20^{\circ} \mathrm{C}$ for $1 \mathrm{~h}$. The DNA was recovered by centrifugation at $14000 \mathrm{rpm}$ for $30 \mathrm{~min}$, and the supernatant was discarded. To wash the pellet, $1 \mathrm{ml}$ of $70 \%$ chilled ethanol was added, and the tube was centrifuged at $14000 \mathrm{rpm}$ for $20 \mathrm{~min}$. The pellet was dried and then dissolved in $50 \mu \mathrm{l}$ of Tris EDTA buffer (Köchl et al., 2004). The purified DNA was then subjected to polymerase chain reaction (PCR) for amplifying the 16S rRNA gene.

\section{PCR amplification of the purified DNA and $16 S$ rDNA sequencing}

PCR was used to amplify the 16S rRNA gene. The primers used for PCR were universal primers: $27 \mathrm{~F}$ forward primer (5'-AGAGTTTGATCCTGGCTCAG-3') and 1492R reverse primer $\left(5^{\prime}-\right.$ GGTTACCTTGTTACG ACTT-3') (Senthilraj et al., 2016). One microliter of purified DNA (10-100 ng) was added to the reaction mixture containing $12.5 \mu \mathrm{l}$ Master Mix (EconoTaq, LUC300352, Sigma-Aldrich), $1 \mu$ l of each of the primers, and $9.5 \mu \mathrm{l}$ of double-distilled water (the final volume was $25 \mu \mathrm{l})$. The master mix consisted of dNTPs, Taq polymerase, $\mathrm{MgCl}_{2}$, and the reaction buffer. The PCR conditions were as follows: an initial denaturation step of 2 min at $94^{\circ} \mathrm{C}$, followed by 35 cycles of $94^{\circ} \mathrm{C}$ for $1 \mathrm{~min}$ (denaturation), $55^{\circ} \mathrm{C}$ for $1.5 \mathrm{~min}$ (annealing), $72^{\circ} \mathrm{C}$ for $1 \mathrm{~min}$ (extension), and then a final extension at $72^{\circ} \mathrm{C}$ for 3 min (ESCO Thermal cycler, Singapore) (Senthilraj et al., 2016). The PCR-amplified products were visualized on ethidium bromide-stained 1\% agarose gel under UV light. The amplified products were gel-purified (HiPurA ${ }^{\mathrm{TM}} \mathrm{PCR}$ product purification kit, HiMedia, India) and sequenced by the Sanger sequencing method using the ABI 3500 Series Genetic Analyzer platform (Thermo Fisher Scientific, USA). The obtained sequences were analyzed using the NCBI BLASTN (https://blast.ncbi.nlm. nih.gov/Blast.cgi) (Gupta et al., 2015) and the Ribosomal Database Project 11 (http://rdp.cme.msu.edu/) (Khaneja et al., 2009). The sequence alignment was performed using Clustal W (https://www.ebi.ac.uk/Tools/msa/ clustalo/), and the phylogenetic tree was assembled in MEGA X (https://www.megasoftware.net/). 


\section{Optimization of growth conditions for the bacterial isolates}

The effect of temperature and salt concentration on bacterial growth was studied by growing the isolates in suspension tubes/96-well plates containing sterile nutrient broth (NB) (MM244, HiMedia Laboratories). The initial culture density of the inoculum was $0.1 \mathrm{OD}$ $(5 \% \mathrm{v} / \mathrm{v})$. The optimum growth temperature of these isolates was determined by incubating the cultures at 10 , 25,37 , and $45^{\circ} \mathrm{C}$. For salt concentration, NB containing $15 \% \mathrm{NaCl}$ concentration was diluted using sterile NB to have a range of salt concentrations, i.e. 15, 12.5, 10, 7.5, $5,2.5$, and $1 \%$. The un-inoculated nutrient broth was kept as a control for both experiments. The optimum growth was evaluated by measuring the absorbance at $600 \mathrm{~nm}$ in an Epoch 2 microplate spectrophotometer (BioTek Instruments Inc., USA). The experiments were performed in triplicates.

\section{Extraction of the pigments}

The pigments were extracted from the cultures by using the solvent extraction method (Numan et al., 2018). The cultures were grown in $\mathrm{NB}$ for 7 days at $37^{\circ} \mathrm{C}$. After culture growth and visible pigment production, the cells were harvested by centrifugation (4000 rpm for $10 \mathrm{~min}$ ), re-suspended in $30 \mathrm{ml}$ methanol, and heated in a water bath at $60^{\circ} \mathrm{C}$ for $30 \mathrm{~min}$. The solutions were centrifuged again at $6000 \mathrm{rpm}$ for $10 \mathrm{~min}$; the supernatants were filtered through a Whatman no. 1 filter paper, collected in Petri plates, and kept at $37^{\circ} \mathrm{C}$ for methanol to evaporate. The dried pigments were collected and dissolved in $5 \%$ methanol for further experiments.

\section{Characterization of the pigments}

\section{UV spectral and FTIR analysis}

The UV-Vis absorption range of pigments was determined by performing their spectral analysis using UVVis spectrophotometry (Epoch 2 microplate spectrophotometer). The pigments solubilized in 5\% methanol were analyzed using methanol as blank. The chemical environments of the extracted pigments were determined by FTIR spectroscopy (FTIR 8700, Shimadzu Co., Tokyo, Japan). The samples (10 mg) were mixed homogenously with dried crystals of $\mathrm{KBr}(200 \mathrm{mg})$ to make pellets and immediately used for the FTIR analysis (in the range of 4000 to $400 \mathrm{~cm}^{-1}$ ) to avoid any water absorption.

\section{Thin Layer Chromatography}

Spots (a drop made using a glass capillary tube) of the extracted pigment samples (dissolved in 5\% methanol) were loaded on commercially available thin layer chromatography (TLC) sheets (stationary phase) (TLC Silica gel $60 \mathrm{~F}_{254}, \mathrm{MERCK}$ ) and run with methanol as a mobile phase. The plate was kept for approximately $20 \mathrm{~min}$ at room temperature in the TLC chamber, followed by drying, and then placed in an iodine chamber for developing the spots.

\section{Estimation of the polyphenol content in the pigments}

The polyphenol content was determined using the Folin-Ciocâlteu colorimetric method (Sarker et al., 2020c). Tannic acid (0-100 $\mu \mathrm{g} / \mathrm{ml}$ in distilled water) was used to prepare the standard curve. The polyphenol concentration in the extracted pigments was quantified in a 96 -well plate. Different concentrations of tannic acid $(100 \mu \mathrm{l})$, $50 \mu \mathrm{l}$ of Folin-Ciocâlteu reagent, and $50 \mu$ of saturated sodium bicarbonate were added to the wells of a 96 -well plate and incubated at room temperature for $1 \mathrm{~h}$. The same protocol was followed for the pigments tested, and $100 \mu \mathrm{l}$ of $10 \mathrm{mg} / \mathrm{ml}$ pigments (in 5\% methanol) were used for the same. The absorbance was measured at $760 \mathrm{~nm}$ by using an Epoch 2 microplate spectrophotometer. The concentration of polyphenols in the pigments was determined using the equation of the standard graph (Sarker et al., 2020c). The polyphenol content was expressed as micrograms of tannic acid (TA) equivalent. The samples were assayed in triplicates.

\section{Determination of the SPF factor of the pigments}

The sun protection factor (SPF) of the pigments was evaluated using a previously reported method (Mansur et al., 1986; Dutra et al., 2004). Briefly, $1 \mathrm{mg} / \mathrm{ml}$ pigment in 5\% methanol was added in a quartz cuvette, and the absorption spectrum was measured between 290 and $320 \mathrm{~nm}$ at $5 \mathrm{~nm}$ interval using an Epoch 2 microplate spectrophotometer. Methanol was used as a blank, and the experiment was performed in three replicates. The SPF factor for each pigment was evaluated using the Mansur equation:

$$
\begin{aligned}
& \mathrm{SPF} \text { (spectrophotometric) }= \\
& =C F \times \sum_{290}^{320} E E(\lambda) \times I(\lambda) \times \operatorname{Abs}(\lambda)
\end{aligned}
$$

where $C F$ represents the correction factor $(=10)$, I represents the solar intensity spectrum, Abs is the absor- 
bance of the sunscreen product, and $E E$ represents the erythemal effect spectrum. $E E \times I$ values are constants (Dutra et al., 2004).

\section{Determination of the antioxidant potential of the pigments}

\section{DPPH assay}

The ability of the pigments to scavenge free radicals was assessed by the DPPH (1,1-diphenyl-2-picrylhydrazyl) assay (Sarker and Oba, 2019b). For the assay, a stock solution of $150 \mu \mathrm{l}$ of DPPH (in $0.1 \mathrm{mM}$ in methanol) and $50 \mu \mathrm{l}$ of $10 \mathrm{mg} / \mathrm{ml}$ extracted pigments (in methanol) were used. The reaction mixture was incubated at room temperature in dark for $30 \mathrm{~min}$, and the absorbance was measured at $517 \mathrm{~nm}$ in an Epoch 2 microplate spectrophotometer. The positive control used for this experiment was ascorbate $(200 \mu \mathrm{g} / \mathrm{ml})$, and the negative control used was $5 \%$ methanol. All samples were assayed in triplicates twice. The formula used to calculate the DPPH scavenging effect was as follows:

DPPH scavenging effect [\%] =

$=\underline{\text { Absorbance of control }- \text { Absorbance of test sample }} \times 100$ Absorbance of control

\section{ABTS assay}

The free radical scavenging ability of the pigments was also evaluated using a more sensitive method, namely the ABTS (2,2' -azino-bis(3-ethylbenzothiazoline-6sulfonic acid) assay (Sarker et al., 2018). A stock solution of $7 \mathrm{mM}$ ABTS and $2.45 \mathrm{mM}$ potassium persulfate was prepared (in distilled water) and mixed in equal volume. The solution was incubated in dark at room temperature for $16 \mathrm{~h}$ for radical generation. The blue/green solution of ABTS was then diluted to an absorbance of $0.70 \pm 0.02$ at $734 \mathrm{~nm}$ by adding absolute ethanol. The positive control used for this experiment was ascorbate $(200 \mu \mathrm{g} / \mathrm{ml})$, and the negative control used was $5 \%$ methanol. In a 96 -well plate, $150 \mu 1$ of ABTS solution was added to $50 \mu \mathrm{l}$ of $5 \mathrm{mg} / \mathrm{ml}$ pigments (in methanol) and incubated for $30 \mathrm{~min}$ at room temperature in dark. Absorbance was determined at $734 \mathrm{~nm}$ in an Epoch 2 microplate spectrophotometer. All samples were assayed in triplicates. The percent of antioxidant activity was calculated as follows:
Antioxidant activity [\%] =

$=$ Absorbance of control - Absorbance of test sample $\times 100$ Absorbance of control

\section{FRAP assay}

Ferric reducing antioxidant power (FRAP) of the pigments was evaluated using a previously described method (Pulido et al., 2000). Acetate buffer $\mathrm{pH} 3.6$ (300 mM), $\mathrm{FeCl}_{3} \cdot 6 \mathrm{H}_{2} \mathrm{O}(20 \mathrm{mM})$, and TPTZ (10 $\mathrm{mM}$ in $40 \mathrm{mM} \mathrm{HCl}$ ) were used as stock solutions. Acetate buffer $(25 \mathrm{ml})$ with TPTZ $(2.5 \mathrm{ml})$ and $\mathrm{FeCl}_{3}(2.5 \mathrm{ml})$ were used as a working solution. The reaction setup used was as follows: $180 \mu \mathrm{l}$ FRAP reagent, $18 \mu \mathrm{l} / \mathrm{W}$, and $6 \mu \mathrm{l}$ test sample. A standard curve was constructed using $\mathrm{FeSO}_{4} \cdot 7 \mathrm{H}_{2} \mathrm{O}$ in the range of $100-1000 \mu \mathrm{mol} / 1$. Ascorbate $(62.5 \mu \mathrm{g} / \mathrm{ml})$ was used as a positive control, and methanol was used as a negative control. The readings were measured at $595 \mathrm{~nm}$ using an Epoch 2 microplate spectrophotometer, and the FRAP activity was determined using the equation of the standard graph $(y=m x$ $+c$ ) and represented as $\mu \mathrm{mol} \mathrm{Fe}^{2+}$ equivalent. This experiment was performed in three replicates.

\section{In vitro protective effect of the pigments against $\mathrm{H}_{2} \mathrm{O}_{2}$} stress in macrophages

The protective effect of the pigments in the presence of $\mathrm{H}_{2} \mathrm{O}_{2}$ stress was shown using the MTT assay (Liu et al., 2010). Murine macrophage cells (RAW264.7) were seeded in a 96 -well plate $\left(2 \times 10^{4}\right.$ cells/well $)$ in DMEM $+10 \% \mathrm{FBS}$ and were allowed to grow at $37^{\circ} \mathrm{C}$, $5 \% \mathrm{CO}_{2}$ for $24 \mathrm{~h}$ in a humidified incubator. After $24 \mathrm{~h}$, the cells were treated with pigments alone or pigments $+\mathrm{H}_{2} \mathrm{O}_{2}$ for $24 \mathrm{~h}$. Pigments at a concentration of $500 \mu \mathrm{g} / \mathrm{ml}$ and $\mathrm{H}_{2} \mathrm{O}_{2}(1 \mathrm{mM})$ were used for the experiment. After the treatment, MTT $(0.5 \mathrm{mg} / \mathrm{ml}$ in DMEM) was added to the cells, and the solution was incubated at $37^{\circ} \mathrm{C}$ for $3 \mathrm{~h}$. The formazan crystals obtained were dissolved with $100 \mu \mathrm{l}$ of $10 \%$ SDS for $2 \mathrm{~h}$. The absorbance was measured at $570 \mathrm{~nm}$ using an Epoch 2 microplate spectrophotometer, and the cell survival percentage with respect to control was determined. This experiment was performed in four replicates.

\section{Statistical analysis}

All the data from the experiments are expressed as mean \pm standard deviation for at least three replicates. 
The results for "In vitro protective effect of the pigments in macrophages" were analyzed using one-way Analysis of Variance (ANOVA) followed by a posthoc Tukey's test in GraphPad Prism 8 software. The differences were considered to be significant at $P<0.05$.

\section{Results and discussion}

Isolation of the bacterial cultures from mangrove soil and water samples, and extraction of the pigments from isolated bacteria

Different colored bacterial colonies were isolated on nutrient agar from mangrove water and soil samples. The bacterial cultures producing pink (MZ) and orange pigment were isolated from mangrove soil, while bacterial culture with yellow pigment was obtained from mangrove water. The isolated strains were identified according to their morphological characteristics and by 16S rDNA sequencing, and the closest prokaryotic matches were determined using the NCBI BLASTN (https:// blast.ncbi.nlm.nih.gov/Blast.cgi) (Gupta et al., 2015) and the Ribosomal Database Project 11 (http://rdp.cme.msu. edu/) (Khaneja et al., 2009). The sequence alignment was performed using Clustal W (https://www.ebi.ac.uk/ Tools/msa/clustalo/), and the phylogenetic tree was assembled using MEGA X (https://www.megasoftware. net/). The colony characteristics, Gram's staining nature, and the image of the pigment producers are provided in Supplementary Figure 1 and Supplementary Table 1 . The $16 \mathrm{~S}$ rDNA sequencing revealed that the bacterial strain producing pink pigment (MZ) showed 98.84\% similarity (NCBI BLAST) and was clustered closely with Bacillus infantis, hence, we concluded that this strain was Bacillus infantis. The bacterial strain producing Yellow pigment showed 73.26\% (NCBI BLAST) similarity with different species of Bacillus, indicating that it belonged to Bacillus spp. For the Orange pigment-producing bacterial strain, NCBI BLAST did not yield any matches. However, based on the Ribosomal Database Project 11 (http://rdp.cme.msu.edu/) (Khaneja et al., 2009) and morphological characteristics (Tang et al., 2017), it appeared to be Halomonas spp. Pigmentproducing Bacillus (Khaneja et al., 2009; Saha et al., 2017) and Halomonas (Cabrera et al., 2007; Fariq et al., 2019) strains are known to be a part of the soil microflora and are recognized to produce the respective colored pigments. The phylogenetic tree constructed using MEGA X software is shown in Figure 1.
Bacteria are a preferred source of pigments because of the controlled and predictable yield (Usman et al., 2017). Here, the pigments were extracted in methanol, and the maximum yield was $0.24-0.26 \mathrm{~g} / \mathrm{l}$ for all the cultures. This yield is considerably high, and it conforms to the yield reported by Fariq et al. (2019) where the maximum yield of carotenoid pigments in methanol extract was around $0.3 \mathrm{~g} / \mathrm{l}$.

\section{Optimization of growth conditions for the bacterial isolates}

For large-scale production of the pigments, the incubation temperature and salt concentrations in the media were optimized (Silva-Castro et al., 2019). All the cultures showed higher growth at 1 and $2.5 \%$ salt concentration in the medium with $\mathrm{OD}_{600}$ of 0.790 for $B$. infantis (MZ) and 1.383 for Bacillus spp. (Yellow) at 1\% salt concentration, and an $\mathrm{OD}_{600}$ of 0.512 for Halomonas spp. (Orange) at $2.5 \%$ salt concentration (Fig. 2A). Our results are in line with those of earlier studies, where carotenoid-producing bacteria were shown to grow at salt concentrations between $0.5 \%$ to $14 \%$ (Saha et al., 2017 ), with an optimum growth at $2 \% \mathrm{NaCl}$ concentration (Kim et al., 2020). Our results also indicate that all the tested cultures can tolerate well up to $15 \%$ salt concentrations; however, the bacterial growth decreased at salt concentrations higher than $2.5 \%$ (Fig. 2A), and the maximum amount of pigment was produced at $2.5 \%$ salt concentration.

Previous studies have indicated that the optimum temperature for growth and pigment production of different pigment producers was $30-37^{\circ} \mathrm{C}$ (Khanafari et al., 2010; Gallardo et al., 2016; Chadni et al., 2017). In fact, for various pigment-producing Bacillus and Halomonas species, the optimum temperature for growth and pigment production was found to be $37^{\circ} \mathrm{C}$ (Cabrera et al., 2007; Saha et al., 2017; Fariq et al., 2019), and our results were similar to the previously reported ones. In our study, all the cultures showed higher growth at $37^{\circ} \mathrm{C}$ with $\mathrm{OD}_{600}$ of 0.870 for B. infantis (MZ), 0.630 for Halomonas spp. (Orange), and 0.770 for Bacillus spp. (Yellow) (Fig. 2B). The growth of $B$. infantis (MZ) $\left(\mathrm{OD}_{600}\right.$ $=0.240)$ and Halomonas spp. (Orange) $\left(\mathrm{OD}_{600}=0.140\right)$ was reduced at $45^{\circ} \mathrm{C}$, but the high temperature did not affect the growth of Bacillus spp. (Yellow) $\left(\mathrm{OD}_{600}\right.$ $=0.520$ ) (Fig. 2B). These results also indicate that all the three cultures could survive in a wide range of tem- 
A

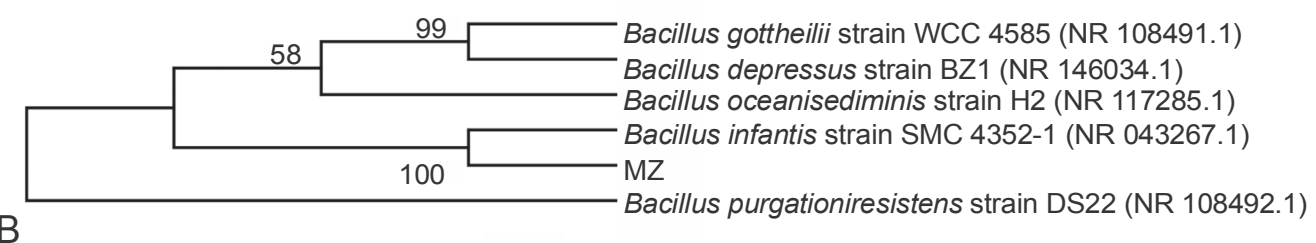

B

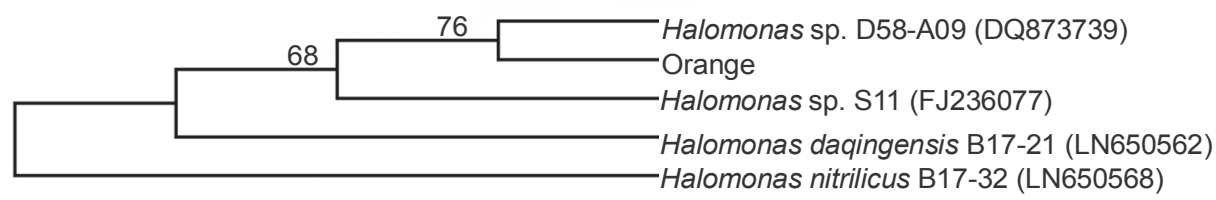

C

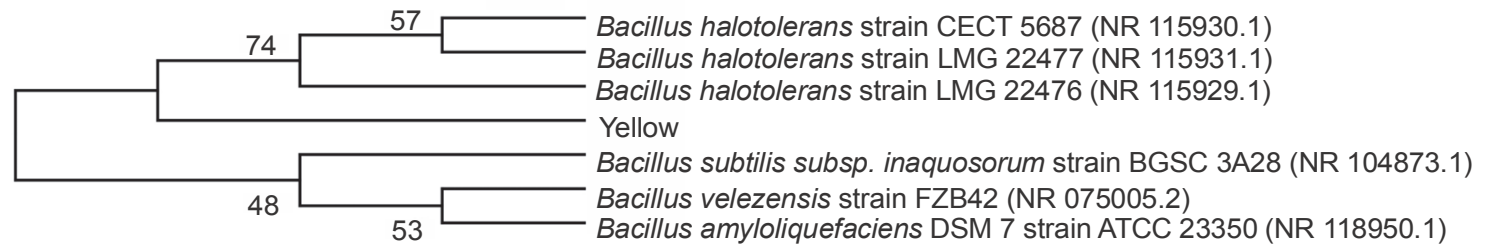

Fig. 1. Phylogenetic relationship tree for A) Bacillus infantis (MZ), B) Halomonas spp. (Orange), and C) Bacillus spp. (Yellow) reconstructed by the neighbour joining method using MEGA X software; the bootstrap value (\%) (1000 subsets) indicates the significance of the branches; GenBank accession numbers are given in brackets

peratures, i.e., between $10-45^{\circ} \mathrm{C}$; however, the optimum temperature for the highest pigment production was found to be $37^{\circ} \mathrm{C}$.

The survival of the tested bacterial isolates in a wide range of salt concentrations and temperatures could be attributed to their habitat and pigment production, as the production of pigments helps bacteria to easily adapt to their respective environments (Sutthiwong et al., 2014; Ramesh et al., 2019). Mangrove rhizosphere is known to have salinity and temperature fluctuations (Simőes et al., 2015; Kharangate-Lad and Bhosle, 2016), and it is evident that these bacteria have adapted to their natural habitat.

\section{Characterization of the pigments}

Partial characterization of the pigments was performed by UV-Vis spectroscopy and FTIR analysis. TLC was performed to assess the components present in the crude pigment extracts (Mulik et al., 2017) (Supplementary Fig. 2). In UV-Vis analysis, the pigments showed absorbance in both UV and visible range, indicating that they had very broad absorption spectra (Fig. 3A). Carotenoids are known to absorb in the UV range (Aust et al., 2005), and carotenoids extracted from extremophilic bacteria that are constantly exposed to solar radiation are also known to protect against UV-A (400-315 nm), UV-B (315-280 nm), and UV-C radiation
(280-100 nm) (Mohana et al., 2013; Reis-Mansur et al., 2019). In our study, the absorption maxima for MZ, Orange, and Yellow pigments in the UV range were $230 \mathrm{~nm}, 210 \mathrm{~nm}$, and $250 \mathrm{~nm}$, respectively (Fig. 3A); this indicated that these pigments could be carotenoids. The absorption maxima in the visible range for these pigments were $480 \mathrm{~nm}, 460 \mathrm{~nm}$, and $410 \mathrm{~nm}$ for MZ, Orange, and Yellow pigments, respectively (Fig. 3A). According to the data reported in the literature, the characteristic absorbance peaks of carotenoids are between $400 \mathrm{~nm}$ and $500 \mathrm{~nm}$ (Scott, 2001; Khaneja et al., 2009; Zaghdoudi et al., 2017; Silva-Castro et al., 2019). The visible ranges of absorption for the extracted pigments were between $410 \mathrm{~nm}$ and $480 \mathrm{~nm}$, which is similar to those described earlier and therefore indicate that these pigments were carotenoids.

In the FTIR analysis, the three pigments showed spectrum patterns similar to those reported for carotenoid pigments (Usman et al., 2018; Cojoc et al., 2019) and derivatives of beta-carotene structure (Neha et al., 2017). The peaks at $1395 \mathrm{~cm}^{-1}$ and $1449 \mathrm{~cm}^{-1}$ represented $\mathrm{C}-\mathrm{H}$ bending frequency along with the presence of methyl groups, and the peak at $2915 \mathrm{~cm}^{-1}$ represented $\mathrm{C}-\mathrm{H}$ stretching (Cojoc et al., 2019). Additionally, peaks were also observed at $1620 \mathrm{~cm}^{-1}$, which indicated the presence of conjugated double bonds of the carbonyl functional group (Usman et al., 2018). The broad peak 


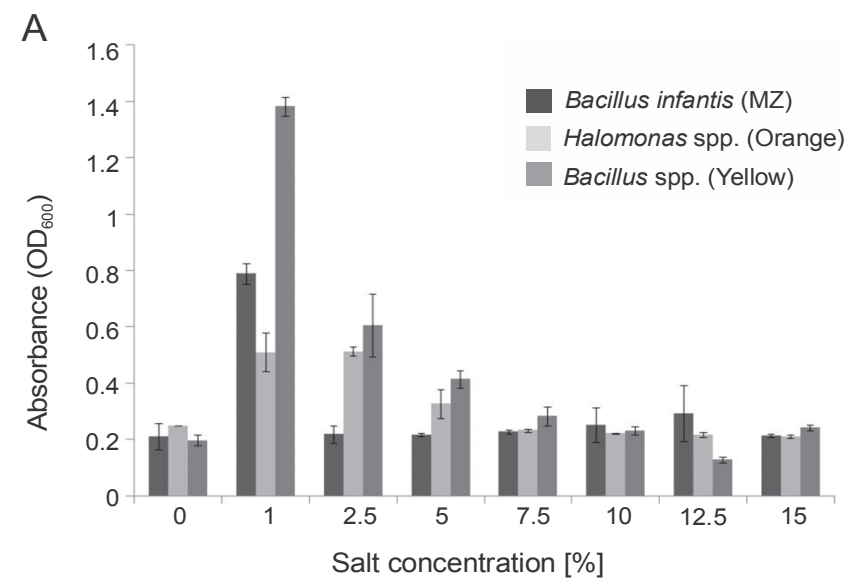

B

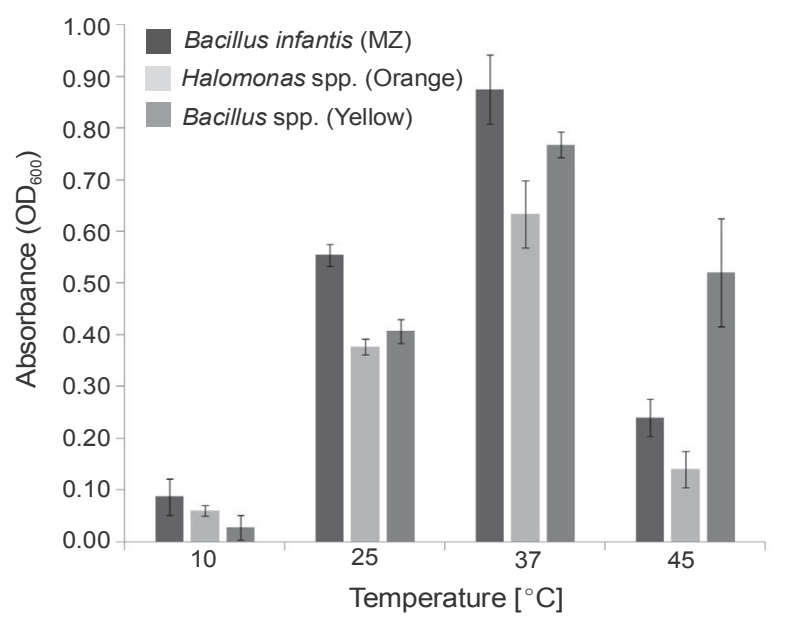

Fig. 2. Optimization of growth conditions for the bacterial isolates Bacillus infantis (MZ), Halomonas spp. (Orange), and Bacillus spp. (Yellow) with respect to A) salt concentration and $\mathrm{B}$ ) temperature

between 3300 and $3500 \mathrm{~cm}^{-1}$ indicated the presence of the $\mathrm{OH}$ or $\mathrm{NH}$ group (Cojoc et al., 2019) (Fig. 3B).

Collectively, on the basis of the results of UV-Vis spectra and FTIR analysis, it was concluded that these extracted pigments were carotenoids.

\section{Estimation of polyphenol content in the pigments and determination of its SPF}

Phenolic compounds are the most studied phytochemicals and are also the major contributors to the antioxidant activity of herbal plants and spices (Shahidi and Ambigaipalan, 2015; Martins et al., 2016). Although plants are the major source of polyphenols, some evidence shows the production of phenolic compounds by microorganisms as secondary metabolites (Kawahara et al., 2012; Bhanja Dey et al., 2016; Tan et al., 2018). Therefore, the polyphenol content of the pigments
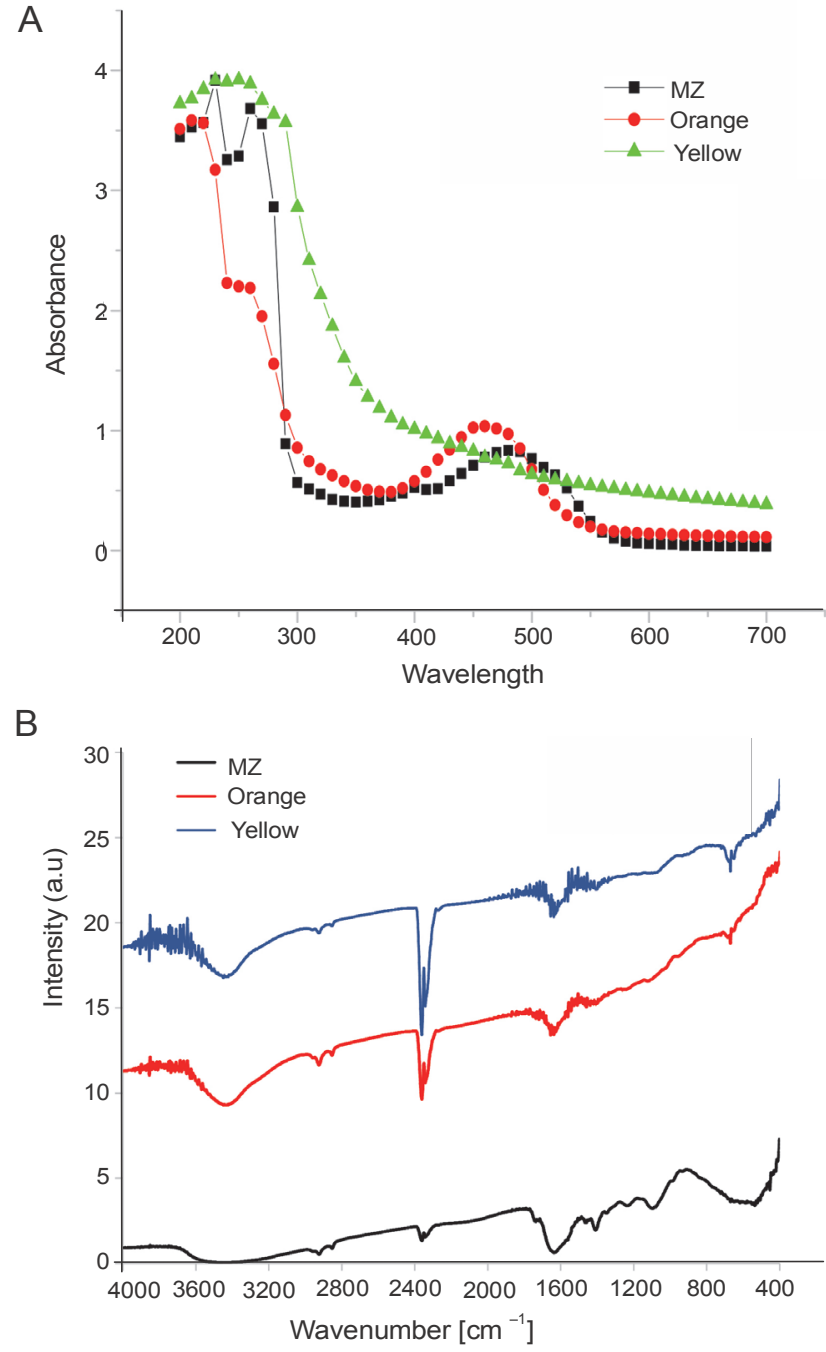

Fig. 3. Characterization of pigments: A) UV-Vis spectrum of pigments indicating that all the three pigments (MZ, Orange, and Yellow) absorb in both UV and visible range and B) the FTIR spectra of the pigments

under this study was estimated using the Folin-Ciocâlteu assay and was found to be the highest for Orange pigment ( $48.8125 \mu \mathrm{g}$ TA equivalent), followed by Yellow (46.5625 $\mu \mathrm{g}$ TA equivalent) and MZ (22.25 $\mu \mathrm{g}$ TA equivalent) (Fig. 4A). In previous studies, the pigments extracted from microorganisms containing polyphenols have been shown to exhibit antioxidant activities (Pawar et al., 2015; Gonçalves Tavares et al., 2018), thus indicating an association of polyphenols with pigments, which contributes to the antioxidant activity of the pigments.

The absorption of the pigments in the UV range indicated that these pigments could act as UV-protective agents. This characteristic was exploited further for the 
A

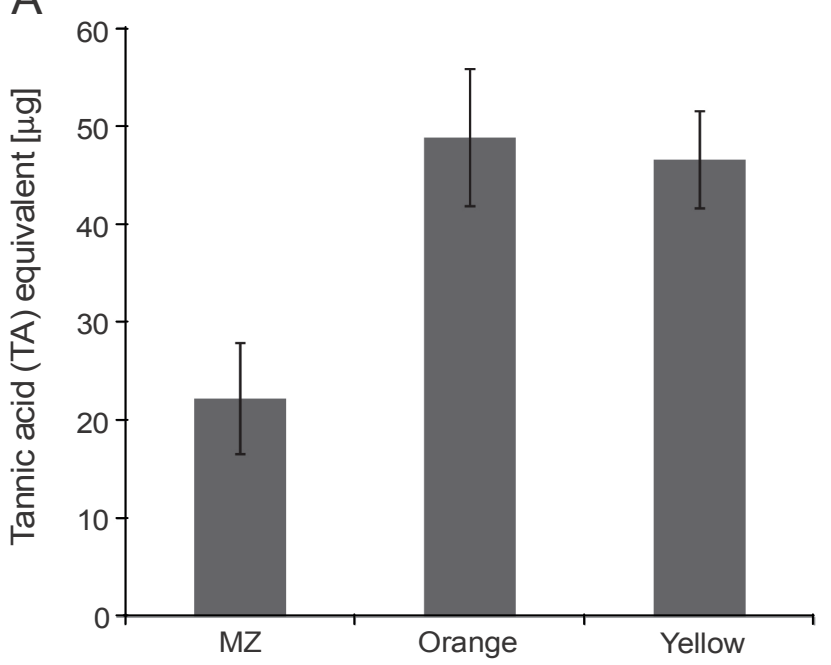

B

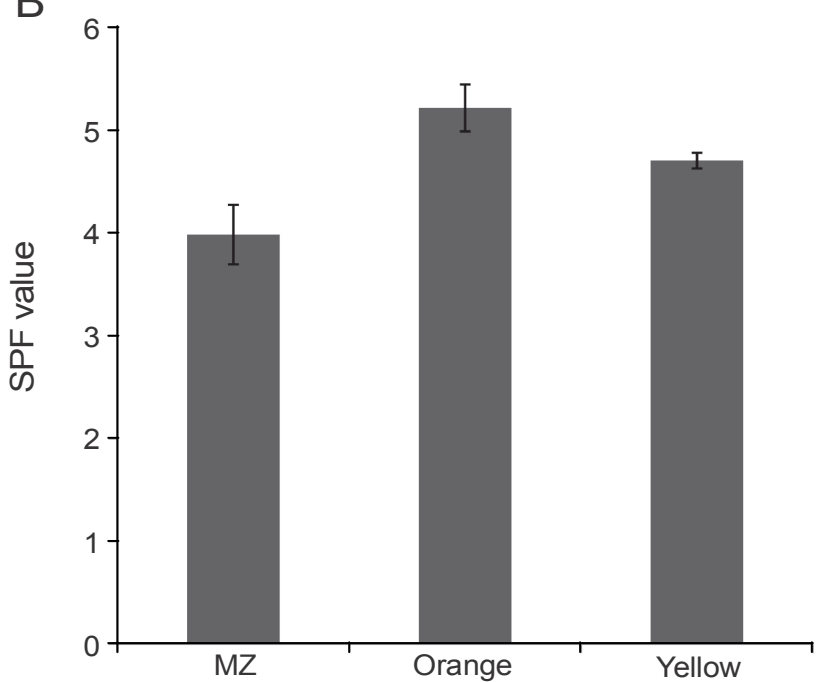

Fig. 4. Estimation of A) polyphenol content in the pigments using the Folin-Ciocâlteu method and B) sun protection factor $(\mathrm{SPF})$ values of the pigments

determination of the SPF values of the pigments by using the Mansur equation (Dutra et al., 2004). It was observed that Orange showed the highest SPF value as compared to the other two pigments. The SPF values were 5.22, 4.71, and 3.99 for Orange, Yellow, and MZ, respectively (Fig. 4B). The values obtained in this study were found to be higher than those reported for the pigments of Exiguobacterium sp. and Serratia marcescens, where the SPF values were found to be in the range of 1.6 to 2.72 (Bana and Heshmatipour, 2014). The effective role of carotenoids in protection against UV light has been reported earlier (Reis-Mansur et al., 2019). It has also been shown that the SPF values of commercial sunscreens can be increased by adding bac- terial or fungal pigments (Suryawanshi et al., 2015; Koli et al., 2019). The SPF value of commercial sunscreens increased by $10-22,20-65,36.5$, and $13 \%$ following the addition of violacein, prodigiosin (Suryawanshi et al., 2015), red pigment, and yellow pigment produced by Monsacus purpureus (Koli et al., 2019), respectively. Because the pigments tested in the present study also have high SPF values, they have the potential to be incorporated into the sunscreens to increase their UV protectiveness.

\section{Determination of the antioxidant potential of the pigments}

A single assay is not accurate enough in determining the antioxidant potential for all the groups of antioxidant compounds; therefore, different assays should be performed to facilitate better comparison and for drawing conclusions (Barros et al., 2017). Hence, in the present study, three assays were performed. DPPH and ABTS assays determine the potential of the pigments to scavenge free radicals (Mohamed et al., 2016). The percent of radical scavenging activity was calculated for the pigments, and all the studied pigments showed significant DPPH scavenging activity. Yellow showed the highest antioxidant activity $(88.62 \%)$ comparable with the ascorbic acid standard (90.95\%), followed by MZ (65.81\%) and Orange (46.8\%) (Fig. 5A). Bacterial carotenoids were previously reported for their antioxidant activities (Manimala and Murugesan, 2014). Approximately $60-80 \%$ antioxidant activity through the DPPH assay was previously reported for pigments extracted from bacteria isolated from mangrove environments (Umamaheswari and Indra, 2013; Raghava Rao and Raghava Rao, 2013; Subramanian and Gurunathan, 2020). In the present study, the extracted pigments exhibited similar antioxidant activity, with the highest antioxidant activity of $88.62 \%$ shown by Yellow pigment.

The studied pigments were also able to scavenge ABTS radicals. MZ (77.26\%) and Orange (75.37\%) showed the highest antioxidant activity comparable to the ascorbic acid standard (74.56\%), followed by Yellow (70.09\%) (Fig. 5B). Our results were similar to those of a previous study where carotenoid pigments from Meiothermus sp. were reported to have an ABTS scavenging activity of around 74.3\% (Mukherjee et al., 2017). However, the pigments in our study showed much higher values than those reported by Park et al. (2018), where 
A

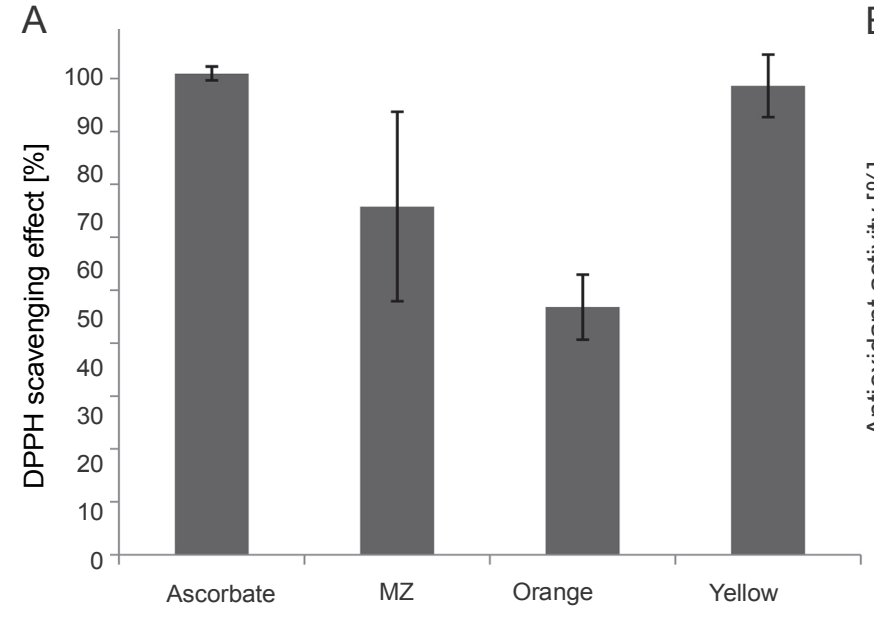

C
B

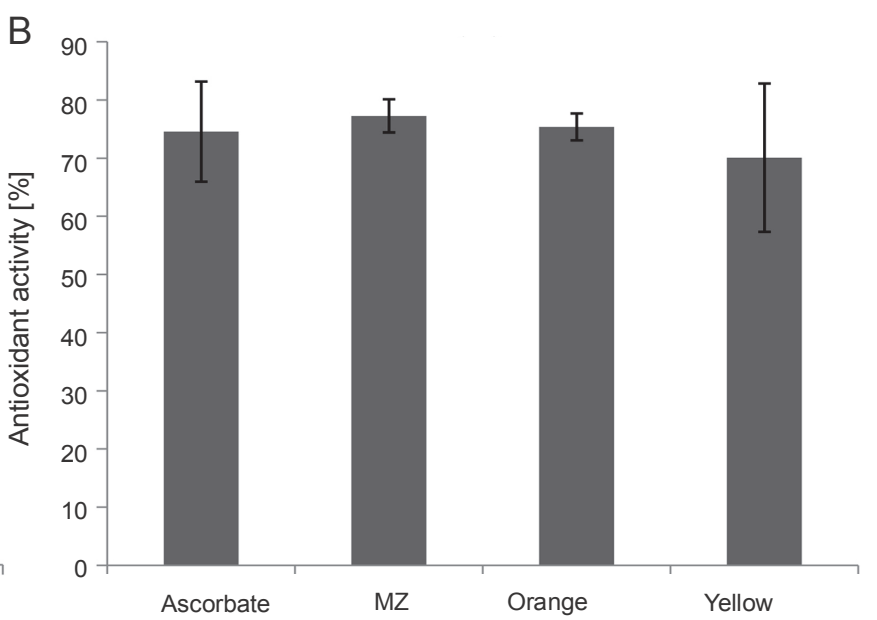

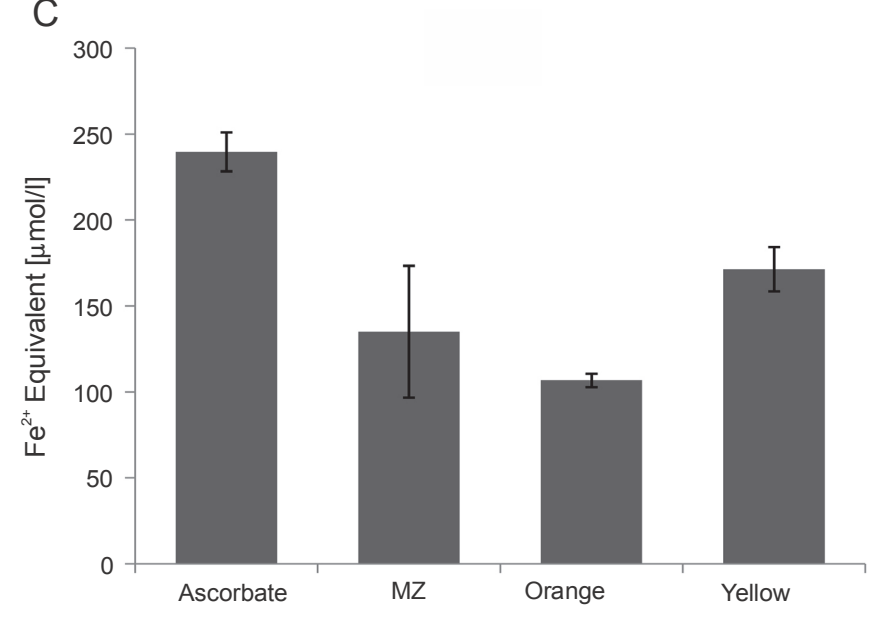

Fig. 5. Antioxidant activity of MZ, Orange, and Yellow pigments demonstrated through A) DPPH (2,2-diphenyl-1-picrylhydrazyl) assay, B) ABTS (2,2-azinobis-3-ethyl-enzothiazoline-6-sulfonicacid) assay, and C) FRAP (Ferric reducing antioxidant power) assay, indicating that these pigments have high antioxidant potential

carotenoids from Arthrospira platensis showed 33.7\% antioxidant activity in the ABTS assay.

FRAP assay also evaluates the antioxidant activity of the pigments (Rizk et al., 2014). By observing the reduction of the colorless $\mathrm{Fe}^{3+}$-TPTZ to indigo-colored $\mathrm{Fe}^{2+}$-TPTZ, the total reducing capacity of the samples was measured, and the antioxidant potential was calculated (Rizk et al., 2014). Among the three pigments, the FRAP value was the highest for Yellow pigment (171.39 $\mu \mathrm{mol} \mathrm{Fe}{ }^{2+}$ equivalent), followed by MZ $\left(135.08 \mu \mathrm{mol} \mathrm{Fe}{ }^{2+}\right.$ equivalent) and Orange (106.75 $\mu \mathrm{mol} \mathrm{Fe}{ }^{2+}$ equivalent) (Fig. 5C). The FRAP value of the ascorbic acid standard was $239.65 \mu \mathrm{mol} \mathrm{Fe} \mathrm{e}^{2+}$ equivalent (Fig. 5C). Our results are in line with previous studies, where significant FRAP activity exhibited by pigments was reported (Salem et al., 2014; Pawar et al., 2015).

Collectively, our data indicated that all three pigments are potent antioxidants. Yellow pigment showed the highest antioxidant potential as compared to the other two pigments in DPPH and FRAP assays. However, in the ABTS assay, MZ showed the highest antioxidant potential. Flavonoid compounds are reported to be more sensitive toward the DPPH assay than toward the ABTS assay (Mohamed et al., 2016); this indicates that Yellow may be a mixture of flavonoids and carotenoids, as observed in other natural products (Wan et al., 2019).

\section{In vitro protective effect of the pigments against $\mathrm{H}_{2} \mathrm{O}_{2}$-induced stress in macrophages}

Because the pigments showed antioxidant properties in chemical assays, their ability to act as antioxidants in the presence of $\mathrm{H}_{2} \mathrm{O}_{2}$ was studied by the MTT assay in murine macrophages. Mouse macrophages (RAW264.7) are known to have a high amount of reactive oxygen species (ROS) and hence act as a good model to study the 


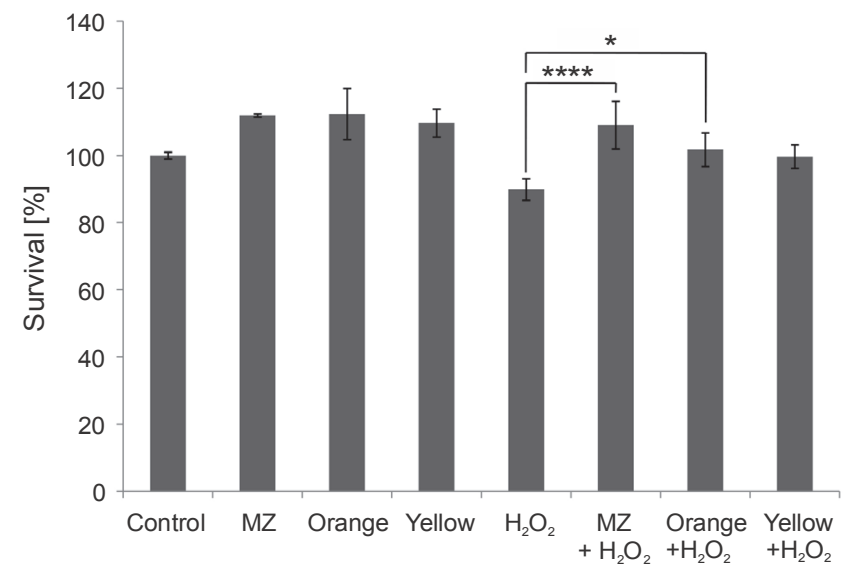

Fig. 6. In vitro protective effect of the pigments against $\mathrm{H}_{2} \mathrm{O}_{2}$ stress in macrophage cell line RAW264.7, indicating that MZ and Orange pigment significantly protect macrophages from

$\mathrm{H}_{2} \mathrm{O}_{2}$-induced cell death. $\left({ }^{* * *} P<0.0001,{ }^{*} P=0.0212\right)$

antioxidant characteristics of any naturally extracted compounds (Castaneda et al., 2017). Exposure to $\mathrm{H}_{2} \mathrm{O}_{2}$ triggers oxidative stress conditions and cell death (Kwon et al., 2019). Previous studies have indicated that pigments prevent $\mathrm{H}_{2} \mathrm{O}_{2}$-induced cell cytotoxicity in retinal pigmented epithelial cells (Huang et al., 2018), HepG2 liver cancer cell line (Fang et al., 2018), and RAW264.7 murine macrophage cell line (Wang et al., 2019). Here, we performed a similar study in macrophages. When macrophages were subjected to $\mathrm{H}_{2} \mathrm{O}_{2}$ stress, $\mathrm{MZ}$ and Orange pigment showed significantly higher protection by increasing the survival percent to 109.016 and $101.7 \%$, respectively, as compared to $1 \mathrm{mM} \mathrm{H}_{2} \mathrm{O}_{2}$ control, which was $89.9 \%$. Yellow also showed a protective effect against $\mathrm{H}_{2} \mathrm{O}_{2}$ stress; however, it was not as effective as $\mathrm{MZ}$ and Orange (Fig. 6).

In previous studies, pigments such as anthocyanins have been shown to prevent $\mathrm{H}_{2} \mathrm{O}_{2}$-induced cytotoxicity in human retinal pigment epithelial cells, wherein blueberry anthocyanin extract (BAE) and malvidin were found to increase the percentage of viability from $63.69 \%$ in $\mathrm{H}_{2} \mathrm{O}_{2}$ treated cells to $86.57 \%$ in BAE-treated cells and to $115.72 \%$ in malvidin-treated cells (Huang et al., 2018). Anthocyanins were also reported to rescue $\mathrm{H}_{2} \mathrm{O}_{2}$-damaged liver cancer cell line HepG2, wherein the red cabbage anthocyanin extract was found to considerably increase the percentage of viability of $\mathrm{H}_{2} \mathrm{O}_{2}$-treated $\mathrm{HepG} 2$ cells (Fang et al., 2018). In one study, astaxanthin, which is one of the xanthophyll carotenoids, was shown to increase the viability of $\mathrm{H}_{2} \mathrm{O}_{2}$-treated RAW264.7 macrophage cells by $49.4 \%$ (Wang et al., 2019).
Our results strongly agree with the results of the abovementioned studies. The results of our experiments were also comparable to the restorative effect of the known antioxidant compounds, namely glutathione (Kwon et al., 2019) and ascorbate (Oh et al., 2020), wherein glutathione was shown to protect RAW264.7 murine macrophages cells and ascorbate was shown to protect ARPE-19 cells (retinal pigment epithelial cells) from $\mathrm{H}_{2} \mathrm{O}_{2}$-induced cell death by significantly increasing the cell viability of $\mathrm{H}_{2} \mathrm{O}_{2}$-damaged cells (Kwon et al., 2019; Oh et al., 2020). These findings indicate that the pigments can protect cells from $\mathrm{H}_{2} \mathrm{O}_{2}$-induced cytotoxicity and act as potent antioxidants.

\section{Conclusions}

In the present study, three different colored pigments were extracted from bacteria isolated from the mangrove rhizosphere habitat. The pigments absorbed in the UV and visible range and had a good SPF value, indicating their potential UV protective properties. The extracted crude pigments had high polyphenol content. Chemical assays and an in vitro cell line-based assay showed that these pigments have high antioxidant potential. Because synthetic antioxidants are known to have adverse side effects, natural and more potent antioxidants will be preferred in future. These natural pigments can be developed as a safer and more effective alternative to the currently used synthetic antioxidants.

\section{Acknowledgments}

We express our sincere gratitude to the Department of Microbiology, St. Xavier's College (Autonomous), Mumbai, for providing laboratory facilities and the required funding for this project. We also thank Ms. Zahabia Patanwala (M.Sc.), Ms. Chelsley Kennedy (M.Sc.), and Ms. Sweta Makwana (M.Sc.) from the Department of Microbiology, St. Xavier's College, for their assistance in the initial part of the project.

\section{References}

Agustina S., Aidha N.N., Oktarina E. (2021) The extraction of antioxidants from Chlorella vulgaris for cosmetics. IOP Conf. Ser. Mater. Sci. Eng. 1011: 012057.

Aust O., Stahl W., Sies H., Tronnier H., Heinrich U. (2005) Supplementation with tomato-based products increases lycopene, phytofluene, and phytoene levels in human serum and protects against UV-light-induced erythema. Int. J. Vitam. Nutr. Res. 75: 54-60.

Bana M., Heshmatipour Z. (2014) Isolation of pigment-producing bacteria from surface water and study of sun protection factor (SPF) of the purified pigments. Iran. J. Public Health. 43: 143-143. 
Barros R.G.C., Andrade J.K.S., Denadai M., Nunes M.L., Narain N. (2017) Evaluation of bioactive compounds potential and antioxidant activity in some Brazilian exotic fruit residues. Food Res. Int. 102: 84-92.

Bhanja Dey T., Chakraborty S., Jain K.K., Sharma A., Kuhad R.C. (2016) Antioxidant phenolics and their microbial production by submerged and solid state fermentation process: a review. Trends Food Sci. Technol. 53: 60-74.

Cabrera A., Aguilera M., Fuentes S., Incerti C., Russel N.J., Ramos-Cormenzana A., Monteolive-Sánchez M. (2007) Ha lomonas indalinina sp. nov., a moderately halophilic bacterium isolated from a solar saltern in Cabo de Gata, Almería, southern Spain. Int. J. Syst. Evol. Microbiol. 57: $376-380$.

Castaneda O.A., Lee S.-C., Ho C.-T., Huang T.-C. (2017) Macrophages in oxidative stress and models to evaluate the antioxidant function of dietary natural compounds. J. Food Drug Anal. 25: 111-118.

Chadni Z., Rahaman M.H., Jerin I., Hoque K.M.F., Reza M.A. (2017) Extraction and optimisation of red pigment production as secondary metabolites from Talaromyces verruculosus and its potential use in textile industries. Myco$\operatorname{logy} 8: 48-57$.

Cojoc L.R., Enache M.I., Neagu S.E., Lungulescu M., Setnescu R., Ruginescu R., Gomoiu I. (2019) Carotenoids produced by halophilic bacterial strains on mural paintings and laboratory conditions. FEMS Microbiol. Lett. 366: fnz243.

Dutra E.A., Oliveira D.A.G. da C., Kedor-Hackmann E.R.M., Santoro M.I.R.M. (2004) Determination of sun protection factor (SPF) of sunscreens by ultraviolet spectrophotometry. Rev. Bras. Cięnc. Farm. 40: 381-385.

Fang S., Lin F., Qu D., Liang X., Wang L. (2018) Characterization of purified red cabbage anthocyanins: improvement in HPLC separation and protective effect against $\mathrm{H}_{2} \mathrm{O}_{2}$-induced oxidative stress in HepG2 cells. Molecules 24: 124.

Fariq A., Yasmin A., Jamil M. (2019) Production, characterization and antimicrobial activities of bio-pigments by Aquisalibacillus elongatus MB592, Salinicoccus sesuvii MB597, and Halomonas aquamarina MB598 isolated from Khewra Salt Range, Pakistan. Extremophiles 23: 435-449.

Foong L.C., Loh C.W.L., Ng H.S., Lan J.C.-W. (2021) Recent development in the production strategies of microbial carotenoids. World J. Microbiol. Biotechnol. 37: 12.

Gallardo K., Candia J.E., Remonsellez F., Escudero L.V., Demergasso C. (2016) The ecological coherence of temperature and salinity tolerance interaction and pigmentation in a non-marine vibrio isolated from Salar de Atacama. Front. Microbiol. 7: 1943.

Gonçalves Tavares D., Viana Lessa Barbosa B., Lopes Ferreira R., Ferreira Duarte W., Gomes Cardosa P. (2018) Antioxidant activity and phenolic compounds of the extract from pigment-producing fungi isolated from Brazilian caves. Biocatal. Agric. Biotechnol. 16: 148-154.

Gupta S., Sharma P., Dev K., Srivastava M., Sourirajan A. (2015) A diverse group of halophilic bacteria exist in
Lunsu, a natural salt water body of Himachal Pradesh, India. SpringerPlus 4: 274.

Huang W.-Y., Wu H., Li D.-J., Song J.-F., Xiao Y.-D., Liu C.-Q., Zhou J.-Z., Sui Z.-Q. (2018) Protective effects of blueberry anthocyanins against $\mathrm{H}_{2} \mathrm{O}_{2}$-induced oxidative injuries in human retinal pigment epithelial cells. J. Agric. Food Chem. 66: $1638-1648$.

Kawahara T., Izumikawa M., Otoguro M., Yamamura H., Hayakawa M., Takagi M., Shin-ya K. (2012) JBIR-94 and JBIR-125, antioxidative phenolic compounds from Streptomyces sp. R56-07. J. Nat. Prod. 75: 107-110.

Khanafari A., Khavarinejad D., Mashinchian A. (2010) Solar salt lake as natural environmental source for extraction halophilic pigments. Iran. J. Microbiol. 2: 103-109.

Khaneja R, Perez-Fons L., Fakhry S., Baccigalupi L., Steiger S., To E., Sandmann G., Dong T.C., Ricca E., Fraser P.D., et al. (2009) Carotenoids found in Bacillus. J. Appl. Microbiol. 108: 1889-1920.

Kharangate-Lad A., Bhosle S. (2016) Studies on siderophore and pigment produced by an adhered bacterial strain Halobacillus trueperi MXM-16 from the mangrove ecosystem of Goa, India. Indian J. Microbiol. 56: 461-466.

Kim I., Chhetri G., Kim J., Kang M., Seo T. (2020) Lewinella aurantiaca sp. nov., a carotenoid pigment-producing bacterium isolated from surface seawater. Int. J. Syst. Evol. Microbiol. 70: 6180-6187.

Köchl S., Niederstätter H., Parson W. (2004) DNA extraction and quantitation of forensic samples using the phenol-chloroform method and real-time PCR. [in:] Forensic DNA typing protocols. Humana Press, New Jersey: 013-030.

Koli S.H., Suryawanshi R.K., Mohite B.V., Patil S.V. (2019) Prospective of monascus pigments as an additive to commercial sunscreens. Nat. Prod. Commun. 14: 1-7.

Kushwaha K., Saxena J., Agarwal M.K. (2020) Identification and characterization of psychrotrophic strain of Planococcus maritimus for glucosylated C30 carotenoid production. Indian J. Exp. Biol. 58: 190-197.

Kwon D., Cha H.-J., Lee H., Hyesook L., Hong S.-H., Park C., Park S.-H., Kim G.-Y., Kim S., Hwang H.-J., et al. (2019) Protective effect of glutathione against oxidative stressinduced cytotoxicity in RAW 264.7 macrophages through activating the nuclear factor erythroid 2-related factor2/heme oxygenase-1 pathway. Antioxidants 8: 82.

Liu J.-H., Chen M.-M., Huang J.-W., Wann H., Ho L.-K., Pan W. H.-T., Chen Y.-C., Liu C.-M., Yeh M.-Y., Tsai S.-K., et al. (2010) Therapeutic effects and mechanisms of action of mannitol during $\mathrm{H}_{2} \mathrm{O}_{2}$-induced oxidative stress in human retinal pigment epithelium cells. J. Ocul. Pharmacol. Ther. 26: 249-257.

Manimala M.R.A., Murugesan R. (2014) In vitro antioxidant and antimicrobial activity of carotenoid pigment extracted from Sporobolomyces sp. isolated from natural source. J. Appl. Nat. Sci. 6: 649-653.

Mansur J., Breder M., Mansur M., Azulay R. (1986) Determinaçăo do fator de proteçăo solar por espectrofotometria. Bras. Dermatol. 61: 121-124. 
Martins N., Barros L., Ferreira I.C.F.R. (2016) In vivo antioxidant activity of phenolic compounds: facts and gaps. Trends Food Sci. Technol. 48: 1-12.

Mohamed S.A., Awad M.A., El-Dengawy E.-R.F.A., AbdelMageed H.M., El-Badry M.O., Salah H.A., Abdel-Aty A.M., Fahmy A.S. (2016) Total phenolic and flavonoid contents and antioxidant activities of sixteen commercial date cultivars grown in Saudi Arabia. RSC Adv. 6: 44814-44819.

Mohana D., Thippeswamy S., Abhishek R. (2013) Antioxidant, antibacterial, and ultraviolet-protective properties of carotenoids isolated from Micrococcus spp. Radiat. Prot. Environ. 36: 168.

Mukherjee T., Bose S., Mukhopadhyay S.K. (2017) Antioxidant properties of the carotenoid extracts of three Deinococcus-Thermus phylum bacteria, Meiothermus sp. strains $R P$ and TP and Thermus sp. strain YY from Paniphala hot spring, India. Nutrire 42: 7.

Mulik A., Kumbhar P., Bhadekar R. (2017) Production and partial characterization of pigments produced by Kocuria sp. BRI 36: Influence of heavy metals. Int. J. Pharm. Pharm. Sci. 9: 137.

Neha T., Shishir T., Ashutosh D. (2017) Fourier transform infrared spectroscopy (FTIR) profiling of red pigment produced by Bacillus subtilis PD5. Afr. J. Biotechnol. 16: 1507-1512.

Numan M., Bashir S., Mumtaz R., Tayyab S., Rehman N.U., Khan A.L., Shinwari Z. K., Al-Harrasi A. (2018) Therapeutic applications of bacterial pigments: a review of current status and future opportunities. 3 Biotech. 8: 207.

Oh S., Kim Y.J., Lee E.K., Park S.W., Yu H.G. (2020) Antioxidative effects of ascorbic acid and astaxanthin on ARPE19 cells in an oxidative stress model. Antioxidants 9: 833.

Park W., Kim H.-J., Li M., Lim D., Kim J., Kwak S.-S., Kang C.-M., Ferruzzi M.G., Ahn M.-J. (2018) Two classes of pigments, carotenoids and $C$-phycocyanin, in spirulina powder and their antioxidant activities. Molecules 23: 2065.

Pawar R., Mohandass C., Sivaperumal E., Sabu E., Rajasabapathy R., Jagtap T. (2015) Epiphytic marine pigmented bacteria: a prospective source of natural antioxidants. Braz. J. Microbiol. 46: 29-39.

Phaniendra A., Jestadi D.B., Periyasamy L. (2015) Free radicals: properties, sources, targets, and their implication in various diseases. Indian J. Clin. Biochem. 30: 11-26.

Pulido R., Bravo L., Saura-Calixto F. (2000) Antioxidant activity of dietary polyphenols as determined by a modified ferric reducing/antioxidant power assay. J. Agric. Food Chem. 48: 3396-3402.

Raghava Rao K.V., Raghava Rao T. (2013) Molecular characterization and its antioxidant activity of a newly isolated Streptomyces coelicoflavus BC 01 from mangrove soil. J. Young. Pharm. 5: 121-126.

Ramesh C., Vinithkumar N.V., Kirubagaran R., Venil C.K., Dufossé L. (2019) Multifaceted applications of microbial pigments: current knowledge, challenges and future directions for public health implications. Microorganisms 7: 186.
Rao M.P.N., Xiao M., Li W.-J. (2017) Fungal and bacterial pigments: secondary metabolites with wide applications. Front. Microbiol. 8: 1113.

Reis-Mansur M.C.P.P., Cardoso-Rurr J.S., Silva J.V.M.A., de Souza G.R., Cardosa V. da S., Mansoldo F.R.P., Pinheiro Y., Schultz J., Balottin L.B.L., da Silva A.J.R., et al. (2019) Carotenoids from UV-resistant antarctic Microbacterium sp. LEMMJ01. Sci. Rep. 9: 9554.

Rizk E.M., El-Kady A.T., El-Bialy A.R. (2014) Charactrization of carotenoids (lyco-red) extracted from tomato peels and its uses as natural colorants and antioxidants of ice cream. Ann. Agric. Sci. 59: 53-61.

Saha M, Afrin S., Sony S., Islam M. (2017) Pigment producing soil bacteria of Sundarban mangrove forest. Bangladesh J. Bot. 46: 717-724.

Saha S., Thavasi R., Jayalakshmi S. (2008) Phenazine pigments from Pseudomonas aeruginosa and their application as antibacterial agent and food colourants. Res. J. Microbiol. 3: 122-128.

Sakihama Y., Yamasaki H. (2021) Phytochemical antioxidants: past, present and future. [in:] Antioxidants [working title]. IntechOpen.

Salem N., Msaada K., Elkahoui S., Mangano G., Azaeiz S., Slimen I.B., Kefi S., Pintore G., Limam F., Marzouk B. (2014) Evaluation of antibacterial, antifungal, and antioxidant activities of safflower natural dyes during flowering. BioMed. Res. Int. 2014: 1-10.

Sandmann G. (2014) Carotenoids of biotechnological importance. [in:] Biotechnology of isoprenoids. Ed. Schrader J., Bohlmann J., Springer International Publishing: 449-467.

Sarker U., Islam M.T., Oba S. (2018) Salinity stress accelerates nutrients, dietary fiber, minerals, phytochemicals and antioxidant activity in Amaranthus tricolor leaves. PLOS ONE 13: e0206388.

Sarker U., Oba S. (2018a) Catalase, superoxide dismutase and ascorbate-glutathione cycle enzymes confer drought tolerance of Amaranthus tricolor. Sci. Rep. 8: 16496.

Sarker U., Oba S. (2018b) Drought stress effects on growth, ROS markers, compatible solutes, phenolics, flavonoids, and antioxidant activity in Amaranthus tricolor. Appl. Biochem. Biotechnol. 186: 999-1016.

Sarker U., Oba S. (2019a) Nutraceuticals, antioxidant pigments, and phytochemicals in the leaves of Amaranthus spinosus and Amaranthus viridis weedy species. Sci. Rep. 9: 20413.

Sarker U., Oba S. (2019b) Protein, dietary fiber, minerals, antioxidant pigments and phytochemicals, and antioxidant activity in selected red morph Amaranthus leafy vegetable. PLOS ONE 14: e0222517.

Sarker U., Oba S. (2020a) The response of salinity stress-induced $A$. tricolor to growth, anatomy, physiology, non-enzymatic and enzymatic antioxidants. Front. Plant. Sci. 11: 559876.

Sarker U., Oba S. (2020b) Leaf pigmentation, its profiles and radical scavenging activity in selected Amaranthus tricolor leafy vegetables. Sci. Rep. 10: 18617. 
Sarker U., Oba S. (2020c) Phenolic profiles and antioxidant activities in selected drought-tolerant leafy vegetable amaranth. Sci. Rep. 10: 18287.

Sarker U., Oba S. (2020d) Polyphenol and flavonoid profiles and radical scavenging activity in leafy vegetable Amaranthus gangeticus. BMC Plant. Biol. 20: 499.

Sarker U., Hossain M.M., Oba S. (2020a) Nutritional and antioxidant components and antioxidant capacity in green morph Amaranthus leafy vegetable. Sci. Rep. 10: 1336.

Sarker U., Oba S., Daramy M.A. (2020b) Nutrients, minerals, antioxidant pigments and phytochemicals, and antioxidant capacity of the leaves of stem amaranth. Sci. Rep. 10: 3892.

Sarker U., Hossain M.N., Iqbal M.A., Oba S. (2020) Bioactive components and radical scavenging activity in selected advance lines of salt-tolerant vegetable amaranth. Front. Nutr. 7: 587257.

Scott K.J. (2001) Detection and measurement of carotenoids by UV/VIS spectrophotometry. Curr. Protoc. Food Anal. Chem. 00: F2.2.1-F2.2.10.

Senthilraj R., Prasad G.S., Janakiraman K. (2016) Sequencebased identification of microbial contaminants in non-parenteral products. Braz. J. Pharm. Sci. 52: 329-336.

Shahidi F., Ambigaipalan P. (2015) Phenolics and polyphenolics in foods, beverages and spices: antioxidant activity and health effects - a review. J. Funct. Foods 18: 820-897.

Silva-Castro G.A., Moyo A.C., Khumalo L., van Zyl L.J., Petrik L.F., Trindade M. (2019) Factors influencing pigment production by halophilic bacteria and its effect on brine evaporation rates. Microb. Biotechnol. 12: 334-345.

Simőes M.F., Antunes A., Ottoni C.A., Amini M.S., Alam I., Alzubaidy H., Mokhtar N.-A., Archer J.A.C., Bajic V.B. (2015) Soil and rhizosphere associated fungi in gray mangroves (Avicennia marina) from the Red Sea - a metagenomic approach. Genom. Proteom. Bioinform. 13: 310-320.

Soliev A.B., Hosokawa K., Enomoto K. (2011) Bioactive pigments from marine bacteria: applications and physiological roles. Evid. Based Complement. Alternat. Med. 2011: 1-17.

Subramanian P., Gurunathan J. (2020) Differential production of pigments by halophilic bacteria under the effect of salt and evaluation of their antioxidant activity. Appl. Biochem. Biotechnol. 190: 391-409.

Suresh K., Prabagaran S.R., Sengupta S., Shivaji S. (2004) Bacillus indicus sp. nov., an arsenic-resistant bacterium isolated from an aquifer in West Bengal, India. Int. J. Syst. Evol. Microbiol. 54: 1369-1375.

Suryawanshi R.K., Patil C.D., Borase H.P., Narkhede C.P., Stevenson A., Hallsworth L.E., Patil S.V. (2015) Towards an understanding of bacterial metabolites prodigiosin and violacein and their potential for use in commercial sunscreens. Int. J. Cosmet. Sci. 37: 98-107.
Sutthiwong N., Fouillaud M., Valla A., Caro Y., Duffosé L. (2014) Bacteria belonging to the extremely versatile genus Arthrobacter as novel source of natural pigments with extended hue range. Food Res. Int. 65: 156-162.

Tan L.T.-H., Chan K.-G., Chan C.K., Khan T.M., Lee L.-H., Goh B.-H. (2018) Antioxidative potential of a Streptomyces sp. MUM292 isolated from mangrove soil. BioMed. Res. Int. 2018: 1-13.

Tang X., Zhai L., Lin Y., Yao S., Wang L., Ge Y., Liu Y., Zhang X., Zhang T., Zhang L., et al. (2017) Halomonas alkalicola sp. nov., isolated from a household product plant. Int. J. Syst. Evol. Microbiol. 67: 1546-1550.

Umamaheswari S., Indra A.P., (2013) Screening of yellow pigment producing bacterial isolates from various ecoclimatic areas and analysis of the carotenoid produced by the isolate. J. Food Process. Technol. 05: 292.

Usman H., Abdulkadir N., Gani M., Maiturare H. (2017) Bacterial pigments and its significance. MOJ Bioequivalence. Bioavailab. 4: 285-288.

Usman H.M., Farouq A., Baki A., Abdulkadir N., Mustapha G. (2018) Production and characterization of orange pigment produced by Halophilic bacterium Salinococcus roseus isolated from Abattoir soil. J. Microbiol. Exp. 6: 238-243.

Vaz-Moreira I., Figueira V., Lopes A.R., Lobo-da-Cunha A., Spröer C., Schumann P., Nunes O.C., Manaia C.M. (2012) Bacillus purgationiresistans sp. nov., isolated from a drinking-water treatment plant. Int. J. Syst. Evol. Microbiol. 62: 71-77.

Wada N., Sakamoto T., Matsugo S. (2013) Multiple roles of photosynthetic and sunscreen pigments in cyanobacteria focusing on the oxidative stress. Metabolites 3: 463-483.

Wan H., Yu C., Han Y., Guo X., Luo L., Pan H., Zheng T., Wang J., Cheng T., Zhang Q. (2019) Determination of flavonoids and carotenoids and their contributions to various colors of rose cultivars (Rosa spp.). Front. Plant Sci. 10: 123.

Wang X., Ma J., Bai X., Yan H., Qin C., Ren D. (2019) Antioxidant properties of astaxanthin produced by cofermentation between Spirulina platensis and recombinant Saccharomyces cerevisiae against mouse macrophage $R A W$ 264.7 damaged by $\mathrm{H}_{2} \mathrm{O}_{2}$. Food Bioprod. Process. 118: 318-325.

Zaghdoudi K., Ngomo O., Vanderesse R., Arnoux P., Myrzakhmetov B., Frochot C., Guiavarc'h Y. (2017) Extraction, identification and photo-physical characterization of persimmon (Diospyros kaki L.) Carotenoids. Foods 6: 4. 